\title{
IMPACTS OF AGRICULTURAL TRANSFORMATION ON THE PRINCIPAL KARSTIC REGIONS OF FRANCE
}

\author{
Jean Nicod and Jean-Noël Salomon
}

\begin{abstract}
The recent extension of intensive agriculture on the karst plateaus has caused different types of impact: soil management, generalised and/or localised pollution. Yet paradoxically rural depopulation can also have negative impacts, which largely depend on the characteristics and the hydrological function of the different karst environments. They are often negative, particularly as far as the water quality is concerned, which is why protection measures are undertaken, either in a defined area for a catchment, or in the framework of regional parks. But this is not always the case, so it is appropriate to analyse the problem of karst pollution as a whole, and to propose to experiment new solutions to mitigate the impacts.
\end{abstract}

KEY WORDS: karst, intensive agriculture, pollution, reserves, France.

\section{Introduction}

Forty percent of French territory is karstic, which gives an idea of the dimensions of the problems caused by the impact of modern agriculture there. These are both numerous and varied, according to the characteristics of the karst areas, bioclimatic conditions and the kinds of agriculture and stock farming which are practised (Tab. 1). In almost all cases the role of soils and epikarst predominate, but in pollution problems the hydrological function of the karst also has a part. The morphoclimatic classification of karst areas, represented by the map of "Karst of France" (Nicod, 1995) can serve as a reference point for this study, since the morphological types under consideration correspond closely to the potential agricultural use.

The most characteristic landscapes are those of medium altitude Mediterranean plateaus: Grands Causses, Causses du Quercy, with their pastures and cultivated karst depressions (dolines and uvalas). Mountain karst of the high alpine type or the forested mountain type (Jura, Alps, Pyrénées) are usually areas for stock farming, but some have been affected by the development of ski resorts. But the most important area for agriculture is the calcareous or chalk plateaus of north-east France, the Paris and Aquitaine basins. They are karst areas covered by residual deposits where the superficial karst forms are poorly developed, but where water percolation (loss) is a general feature. Because of their soil quality and relative flatness, they are suitable for intensive agriculture, but unfortunately also very susceptible to erosion. Moreover, the endokarst is mostly composed of conduits with underground streams, which facilitate the rapid transfer of pollutants.

If the intensification of agricultural production plays a major part in erosion and 


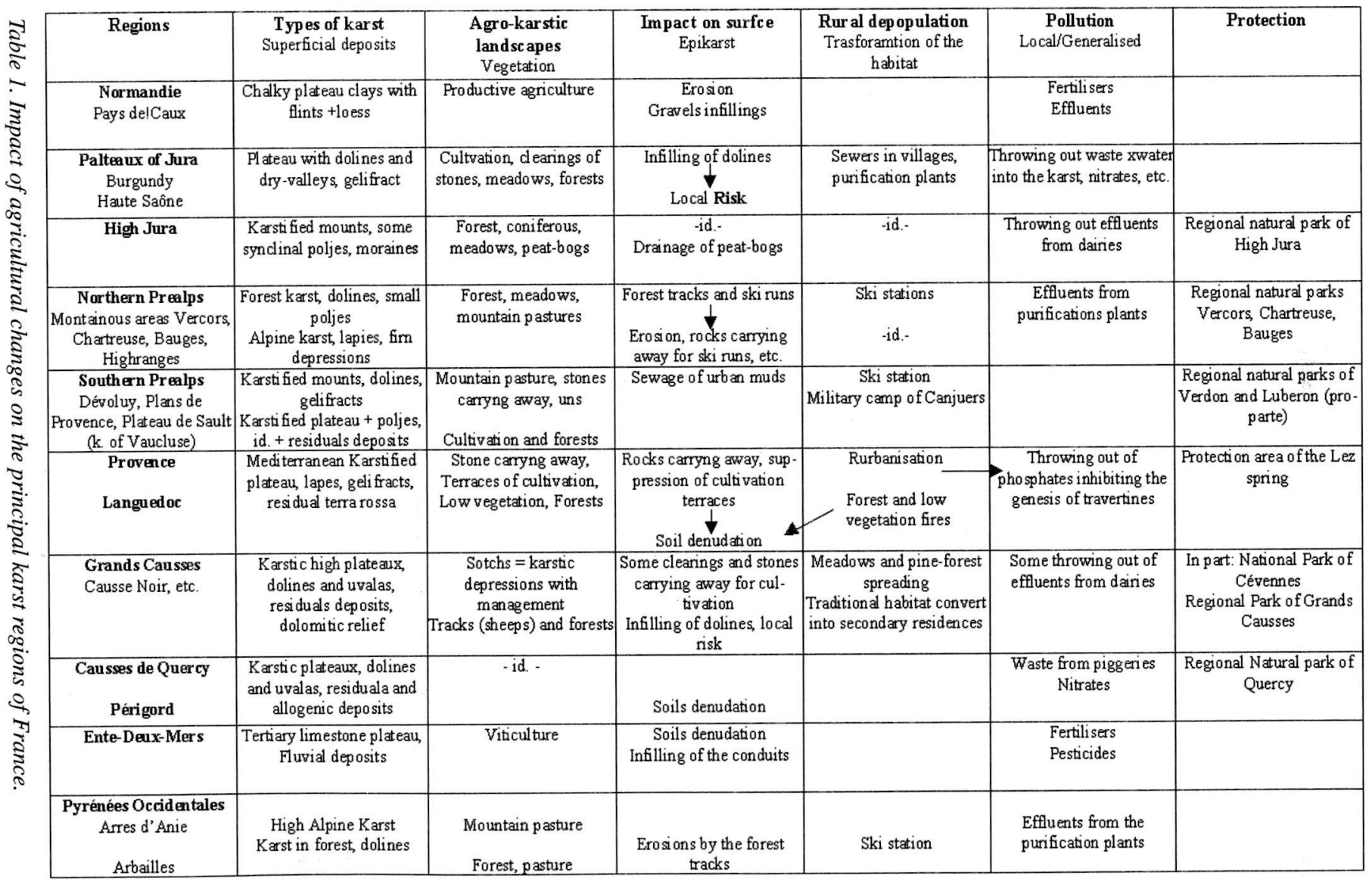


pollution problems, it can be seen, paradoxically, that depopulation of rural or mountain areas, after other activities have been introduced, can play a harmful role: this is particularly the case for Mediterranean karst plateaus subject to rurbanisation.

\section{Changes on the karst surface: mechanisation and abandonment of traditional methods.}

The advent of intensive agriculture has completely overturned the French rural landscape in a few decades. Karst regions have not escaped this fundamental change.

\subsection{Soil erosion}

Most of the karst plateaus of low and medium altitude have been cultivated since the Neolithic, once the soils were sufficiently thick and fertile. According to individual circumstances, these soils are developed on weathered residues (red earth from the Causses, clay with flints from the chalk plateaus or chert from the calcareous plateaus of Burgundy and Franche-Comté) and/or loess of varying thickness. Conversely, forests have often been maintained on siliceous cover deposits.

The amalgamation of landholdings and the development of mechanised agriculture have led to deep ploughing over large areas devoted to monoculture. Winter rains and also sometimes summer storms can cause considerable erosion ${ }^{1}$. Turbid waters absorbed by infiltration into the epikarst and streamsinks contribute to the siltation of passages and to the pollution of springs. The impact of this amalgamation and agricultural practice has often been noted (Salomon, 1998), and particularly in the calcareous regions: calcareous plateaus of the Jura (Renault, 1990) and of eastern France (Treffot, 1992); Normandy (Rodet, 1992); Entre-deux-Mers in the Gironde (Audra, 1998).

In periods of flooding, there can be considerable turbidity at springs: in northern Lorraine on the interfluvial karst of Loison-Othain, measurements taken at the "Bouillons of Delut" (overflow springs) show that specific degradation reaches 104 $\mathrm{t} / \mathrm{km}^{2} / y e a r$ in some small cultivated valleys, as compared to 34 for those under forest or grass cover, and that $70 \%$ of the transported material in the Delut basin leaves via the overflow outlet (Gamez, 1995). In the Grands Causses, evidence of accelerated erosion has been noted in the dry valleys of the Causse Noir, when torrential rain fell from 20-21 September, 1980 (Nicod, 1991a). On the Larzac Causse, in Portalerie aven (shallow hole), a huge accretion of debris resulted from material from recently cleared land (Bruxelles, 1995). Often the abandoning of traditional management techniques must also be questioned, sometimes resulting in cessation of the formation of concretions (Cabrol, 1989).

\subsection{The filling in of dolines, a factor of instability.}

Even if the practice to fill the dolines is an ancient use, the mechanisation of agri-

${ }^{1}$ Example of the storm at Vaupalière, near Rouen, 11 June 1997, when a mud slide killed 3 people. 
culture is making this widespread custom on many plateaus (Jura) and in covered karst. The dolines are more or less active, depending on their origin: accelerated solution in a fissured zone, a sink obstructed by a plug of debris, deep-weathering, etc. also in relation with the morphoclimatic conditions. Periods of prolonged rain often result in accelerated undermining; by changing the hydrological conditions, heavy showers can cause swift removal of blockages (Mouret, 1984; Rodet, 1992). On the Amancey plateau near Deservillers (Doubs), filling in of dolines as part of agricultural practice is very evident: in one of them a sack of fertiliser was buried under 40 $\mathrm{cm}$ of earth for over 15 years. There are many examples of undermining and re-opening of doline bottoms (Gaiffe and Bruckert, 1985).

With the help of a bulldozer, it is possible to reveal systematic filling in, like those at Villeguindry, on the plateaus of the Haute-Saône (Nicod, 1984). It consists of piling up branches, then stones and earth from neighbouring fields in order to level the slopes (Fig.1 a and b). One may well wonder about the long-term stability of such a method. In the Grands Causses, in Larzac, in places where there is a depth of "terra rossa", farmers practice the systematic filling-in of dolines, but there is no lack of recurrence of undermining (Bruxelles, 1995). In the vineyards of Entre-deux-Mers, the levelling done by bulldozer are affected by a process of subsidence due to downwashing of surface deposits into the karst passages of the underlying limestone (Audra, 1998).

\subsection{Abandonment of traditional crop farming methods}

On the Grands Causses the "sotchs" (dolines) and uvalas were carefully managed areas for growing cereals: stony soils with dry-stone walls on their perimeter, banks created in dry valleys... The use of large machines and the extension of pasture (increased sheep rearing for the production of Roquefort) tends to destroy traditional management, particularly on the Causse Méjean (Fig. $1 \mathrm{c}$ and d), and to encourage soil erosion.

In Provence and Languedoc, new vineyards established on slopes and in karst valleys are on a large scale and much more extensive than the traditional method, the "restanques". There are no walls and the stones are shattered. Deep ploughing done by powerful machinery attacks the base of the slopes, involving pockets of terra rossa. These extensions of vineyards are particularly prevalent in some communes of Var (the cantons of Cotignac and Lorgues) where this type of soil is sought after for production of A.O.C. wines (Appellation d'Origine Contrôlée). In periods of strong Mediterranean showers the crypto-lapies are exposed in the marginal areas of depressions and small valleys: erosion scars appear on the slopes and debris accumulates at the base. It is also noted that increased turbidity in springs and streams is one of the major causes of the cessation of deposition of travertine (Vaudour, 1986).

\subsection{The role of rural depopulation: causes and multiple effects.}

Numerous problems have also arisen from the decline or abandonment of agriculture, but the causes and effects are very different, according to the morphoclima- 

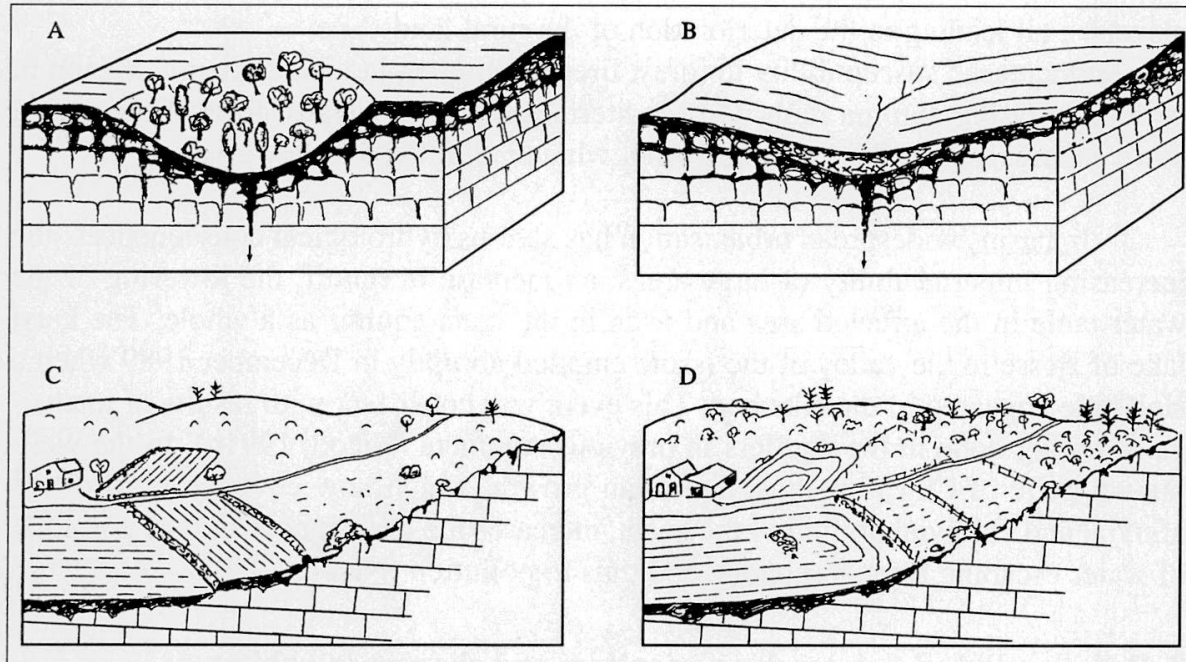

Fig. 1. Transformation of the karst surface

$a$ and $b$ - Infilling of a doline at Velleguindry, on the Haute-Saône plateaus (Nicod, 1984).

$c$ and $d$-Change in agricultural areas on the Causse Méjean.

$c$ - conditions during Marres time in 1935: fields enclosed by stone walls and saltus;

$d$ - present conditions: fields for grazing, brushwood and extension of pine forests (Cohen, 1995).

tic conditions and the location of karst areas.

1 - High mountain areas, the installation of ski runs on alpine pastures induces erosion and degrades the vegetation cover. Thus, on Margeriaz, in the Bauges massif in Savoy, the alpine pasture has been completely disrupted (Hoblea, 1990). The situation is worse on the alpine pastures of La Plagne, on a gypsum karst: sink holes have appeared on the ski tracks (Rovera, 1990). Moreover, heavy winter usage brings the risk of pollution because of a lack of a waste water purification plant, as is the case at Flaine in Savoy or at Pierre Saint-Martin in the western Pyrenees (Douat and Salomon, 1994), waste water from dwellings is discharged directly into the karst.

2 - On karst plateaus of medium and low altitude, the effects of depopulation are demonstrated by the extension of brush cover and pine plantations, as in the dolomite areas of the Grands Causses or on the Plans of Provence. In the latter case, the creation of the largest military camp in Western Europe at Canjuers in the 1970s had a particular effect. Generally the effects in Languedoc and Provence are the extension of fallow land in the face of "rurbanisation". Rural depopulation has two main consequences:

- the abandonment of traditional agrarian techniques (terracing, stone walls bordering rural roads and "drailles"2, wells and dry-stone constructions (bories, 
mazets) ${ }^{3}$, all leading to the deterioration of the rural landscape;

- an increased susceptibility to forest fires in summer, inducing intense erosion in periods of heavy autumn rains. On Mediterranean karst plateaus, forest fires have a more general impact than wine growing, which is limited to a few areas.

3 - In basins widespread urbanisation has serious hydrological consequences: the increasing impermeability of large areas, an increase in runoff, the lowering of the water table in the affected area and even in the karst aquifer as a whole. The karst lake of Besse in the valley of the Issole emptied abruptly in December 1989 when a sink hole appeared in the lake bed. This event was consistent with results of intensive sampling done in the aquifers in previous summers (Nicod, 1991b). In the wellknown polje of Cujes-les-Pins, the urban growth, which now covers a third of the alluvial and colluvial bottom of the basin, increases the karst runoff and the pollution of water escaping through ponors, and thus to pollution (Nicod, 1990).

\section{Pollution linked to intensive agriculture and changes in habitat.}

\subsection{Three types of pollution can be distinguished:}

1 - Direct pollution on the karst. In spite of "Martel law" on public health and hygiene (15.2.1902), speleologists still, at the end of the 20 th century, record occasional cases of animal carcasses which have suffered from disease found in caves (Causses, Pyrenees, Plans of Provence, etc.), grape must (Entre-deux-Mers) or dairy effluent as on the Comtal Causse (Dodge, 1982). Some disposal sites for carcasses, like that of Barrenc de Picausel in the Pays de Sault (Aude), have had to be cleaned up. The Hourat canyon at Laruns (Western Pyrénées) covered with bones and decomposing entrails over an area of several hundred metres, was even the subject of legal action. In Orcheval Cave (Doubs) forty car bodies had to be removed. Unfortunately, uncontrolled and illegal rubbish disposal are very frequent in karst areas. Even more serious is the disposal of industrial waste (chemical, pharmaceutical, hydrocarbons) in caves, and even the army has been guilty of this kind of practice: in the inter-war period, huge stocks of ammunition and gas were stored in Jardel Cave (Doubs) by the army. They are still there (F.F.S., 1993).

Organic matter and chemical products gradually break down and are washed into the stream systems, and spread into fissures, retaining their toxicity. These all constitute a serious threat to aquifers and springs in the countryside.

2 - Pollution by effluents which filter down into the karst comes mostly from farms, piggeries, dairy farms, especially in areas where production is dispersed, as in the Grands Causses or the Upper Jura. Residue from cheese factories constitutes a

2 "Drailles" are former transhumance tracks used mainly for sheep.

3 "Bories" and "mazets" are former stone shelters used by shepherds on a temporary basis. Because of the concentration of cheese maturing at Roquefort, pseudo caves ("caves bâtardes"), created for cheese makers on the Causses, have been abandoned (Gauchon, 1997). 
veritable bacteriological soup which pollutes a large part of the Jura plateau. If the villages have a sewer system and a purification system, any breakdown in this system can cause concentrated pollution through the accumulation of effluents. On the Jura plateaus, this is illustrated by the example of Belleherbe village (Doubs), whose drinking water came from a karst spring contaminated by its own purification system (CREPSC, 1981)! Many other cases of virtually closed systems have been recorded, particularly in mountain areas where purification systems do not function well in winter. There are numerous sources of pollution in the countryside. There are numerous examples of hydrocarbons (from garages, quarry sites, road works, etc.) salt spread on the roads to counteract ice (Source des Godeliers, Le Torpt, Eure), industrial waste (toxic varnishes polluting the Dortan blue spring in Ain), or accidental spills (5,000 1 of fuel-oil spilt in 1977 above Bourrugues Cave at Arette, in the western Pyrenees). Finally, on the Mediterranean karst plateaus, rurbanisation carries an increased risk of pollution, linked to the poor functioning of septic tanks or waste water, spilled directly into the ground or into a drainage sink or into the soil.

\section{3 - Generalised pollution from various sources.}

The most wide-spread type of pollution on the karst plateaus comes from the use of liquid manure and fertilisers and the use of herbicides and pesticides, employed in either mechanised agriculture or intensive stock-rearing (battery farming of cattle, sheep, pigs and fowls). The general problem of the high nitrate levels in spring water and ground water is well known, as is that of the eutrophisation of rivers in summer.

There are more specific cases of pollution on karst to be identified: the use of residual mud from purification stations, either used to encourage grass regrowth on ski runs (Hoblea, 1990), or as an aid to cultivation on stony or leached soils. On the Albion plateau (Vaucluse), residual mud very rich in organic matter and agents of bacterial activity from the SANOFI factory (manufacturing gelatine) at l'Isle-surSorgue is used.

\subsection{Means of introduction and transfer of pollutants.}

The extent, importance and evolution of agricultural pollution by various means in karst areas depends on different factors.

\section{1 - Geographical factors.}

Depending on the individual case, pollution is characteristic of the karst surface under consideration (e.g. the Grands Causses) or of catchments from which absorbed allogenic water originates (e.g. Ouysse spring in Quercy, where according to Coustou (1979), 38\% of the flow comes from upstream of the karst) (Fig. 2a). In general, pollution varies in inverse proportion to the extent of woodland, hence the importance of the conservation of forest areas in order to protect some spring used for water supply.

In the case of infiltration into the karst surface, the type and thickness of the soils 


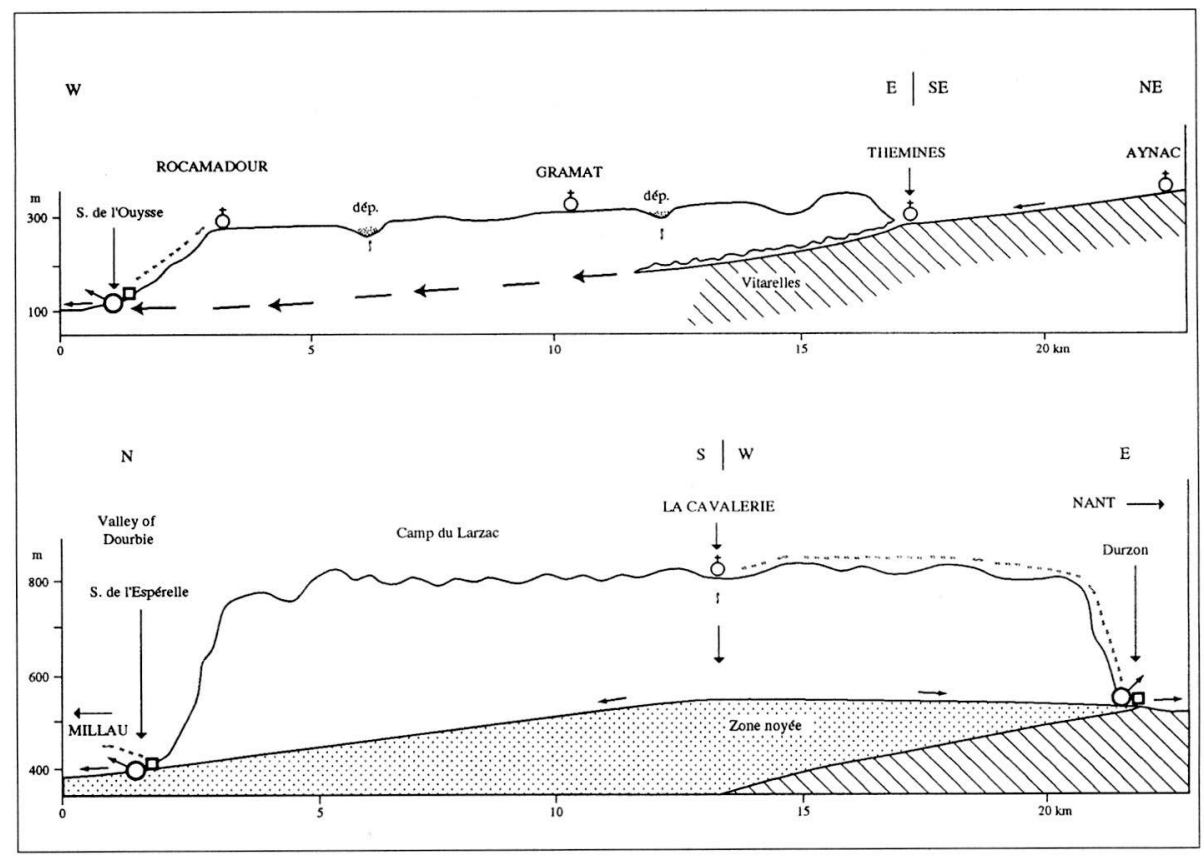

Fig. 2. Two cases of pollution transfer in karst plateaus.

$a$ - In the Causse de Gramat (Quercy), pollution of the karst system of the Ouysse. Deposits from the sub-aerial basin upstream, and pollution sites on the Causse itself. Underground rivers and rapid transmission of pollutants (Coustou, 1974).

$b$ - In north Larzac, pollution of Durzon spring (water catchment for La Cavalerie) and Esperelle spring, supplying Millau. Buffer effect of the satured zone (Ricard and Bakalowicz, 1996).

and superficial deposits, the karstic meso-forms (dolines, sinkholes) and the structure of the epikarst play an important role in the ways pollution is introduced. In the Upper Jura, glacial deposits in synclinal valleys limits the introduction of pollutants. Yet on 21 June, 1986, the watershed of the Grotte des Foules supplying the town of St Claude was seriously contaminated after a heavy storm (causing run-off) by Septmoncel manure heaps on the slopes of the catchment. In the Pays de Caux (Normandy), which is a karst covered by clay with flints and loess, pollution penetrates in the winter period or in summer storms by the run-off absorbed in streamsinks. The increase in mechanised agriculture and soil erosion have only made things worse (Conrad et al. 1988; Rodet, 1982, 1992).

Dolines with clayey bottoms are preferred sites for rubbish dumps everywhere, but the base is rarely impermeable (percolation, adsorption, reopening). An aberrant practice in Larzac consisted in removing the clay from the doline before using it as solid waste disposal (Bruxelles, 1995). 


\section{2 - Endokarstic factors}

Hydrogeologists have published many works on the conditions of transfer of pollutants in karst aquifers (Mangin and Bakalowicz, 1989; Blavoux et al. 1991/1992; Guillemin and Roux, 1992; Ricard and Bakalowicz, 1996, etc.).

On the most of the karst plateaus, because of the slight thickness of the limestone series, underground circulation close to the underlying impermeable layer (aquiclude, a satured zone of low capacity) often results in a rapid transfer of pollutants, especially if meteorological and hydrological conditions are favourable. An extreme case of transfer is that of Bramabiau - famous since Martel: the turbidity and pollution of the Bonheur stream, which comes from Aigoual, are transferred there solely by the cascading underground river (Fabre and Maurin, 1985).

Conversely, the Grands Causses (with thick limestone series and a synclinal structure) and the majority of Mediterranean karsts have a large saturated zone, complex networks and vauclusian-type resurgences. This endokarst structure assures some dispersion of pollutants and their storage at different levels. A part can be absorbed by clay and some self-cleaning is even possible by the activity of underground aquatic fauna, which develops due to the influx of organic matter and nitrogen coming from the surface and from the epikarst (Creuze des Chateliers et al., 1991).

Thus the Fountain of Vaucluse is relatively unpolluted, in spite of the agricultural zone of the Sault valley and the Albion plateau, the use of fertiliser and residual mud, various rubbish dumps and the effluent from purification plants. This is due to the extend of its catchment (more than $1,100 \mathrm{~km}^{2}$ ), to the large proportion of upland and forested land, to the small proportion (8\%) of absorbed river water (R. Nesque) contributing to its discharge, but mostly to a very large saturated zone with a considerable storage capacity (dynamic volume of the order of $100 \times 10^{6} \mathrm{~m}^{3}$ and the role of annexed reserves). Numerous dye-tracings and hydrochemical and isotopic analyses have revealed the complexity of the functioning conditions of the aquifer, and testify its relative immunity to agricultural pollution (Blavoux et al., 1991/1992; unpublished report by Puig). Similarly, in the Sainte-Baume massif, the Saint-Pons spring is still trouble free (Martin, 1991).

\subsection{Consequences of pollution of agricultural origin or pollution linked to changes in the rural habitat.}

We will not dwell on consequences of an epidemiological nature (Moreau, 1982), especially accidental ones, nor on the unpleasant conditions experienced by speleologists in some underground networks which are little better than sewers. The excessive use of fertilisers creates a more general problem of increased content of nitrates and phosphates in drinking water supplies (A.E.P.) or pollution of bacteriological origin as illustrated by waste effluents from battery farming (cf. infra.).

Two similar problems must be stressed since they have serious consequences on spring water and the resulting rivers:

- in the interior of karst, the hypogean subterranean fauna can be degraded and 
then lose its capacity to purify (Creuze des Chateliers et al., 1991);

- in rivers, excessive amounts of phosphates (mostly from laundries) have an inhabiting effect on Cyanophytes which fix $\mathrm{CaCO}_{3}$ (Casanova, 1986). Because of this it is difficult for travertine dams to be maintained, the damp ecological environment tends to dry out and thus lose its purifying power.

\subsection{An example of "moderate" pollution: the northern Causse of Larzac}

This karst sustains two main springs (Fig. 2b): Durzon spring upstream of the Dourbie canyon, and the Esperelle spring which is tapped downstream for the town of Millau water supply. They are Vauclusian springs from a complex aquifer in the thick carbonate series of the middle and upper Jurassic of the Grands Causses: vadose systems and an extensive phreatic zone (Ricard and Bakalowicz, 1996). The pollution is dispersed with the use of fertiliser for artificial meadows, a few dairy farms and sewage disposal plants, a military camp and the Cavalerie treatment plant. This pollution is introduced into the karst because of the nature of the topography (dolines, fissures, avens, etc.) and fluctuates according to hydrological conditions (Ambert et al., 1992). Water from the Durzon spring, polluted to some extent by agriculture on the Causse, is used for the Cavalerie water supply, while its treatment plant accidentally pollutes the Esperelle spring, which provides Millau water supply!

It is of general note that on the karst plateaus, the expansion of the drinking water supply system causes an increase in waste water, and so increases the risks of pollution.

\subsection{Pollution linked to intensive agriculture.}

The Causses of Quercy is an excellent example of pollution linked to intensive agriculture (Salomon and Tarrisse, 1998). The soils are poor, thin and unsuitable for intensive agriculture. They were traditionally used for extensive agriculture and sheep rearing. Hence with the modernisation of agriculture, the Quercy plateaus have been seriously affected by the rural exodus. To check this process, financial aid has been provided, allowing the development of intensive stock rearing, particularly battery pig farms, with sometimes as many as 1,000 pigs per unit. Pigs are three times more polluting than humans. Moreover, the pig farms have been developed with no thought for the treatment of concentrated affluent nor for the increase in turbidity linked to changes in surface land features (uprooting hedges, and amalgamation of cultivable land) and cultivation methods (increasing use of machinery, deep ploughing). The result is increased pollution of springs, often visible by their reddish discolouration.

Pollution has been proved by several studies based on sampling at the springs and also inside the underground networks. In 1998, the Bramarie-St. Sauveur system (NW Causse of Gramat) was in receipt of 10,110 human equivalents of pollution, which constituted a doubling of amount in 15 years. Bacteriological pollution was measured (coliform, streptococcal, faecal, spores) which made the water unfit for human consumption, and its origin traced to the pig-rearing units. Similar studies 
have been made on the karst system of the Causse of Cesarines (the eastern extension of the Causse of Padirac) and on the Causse of Cregols (12 km Causse of Limogne), giving equally disastrous results (Fig. 3).

More than a thousand analyses of the nitrates content of water from Dordogne,

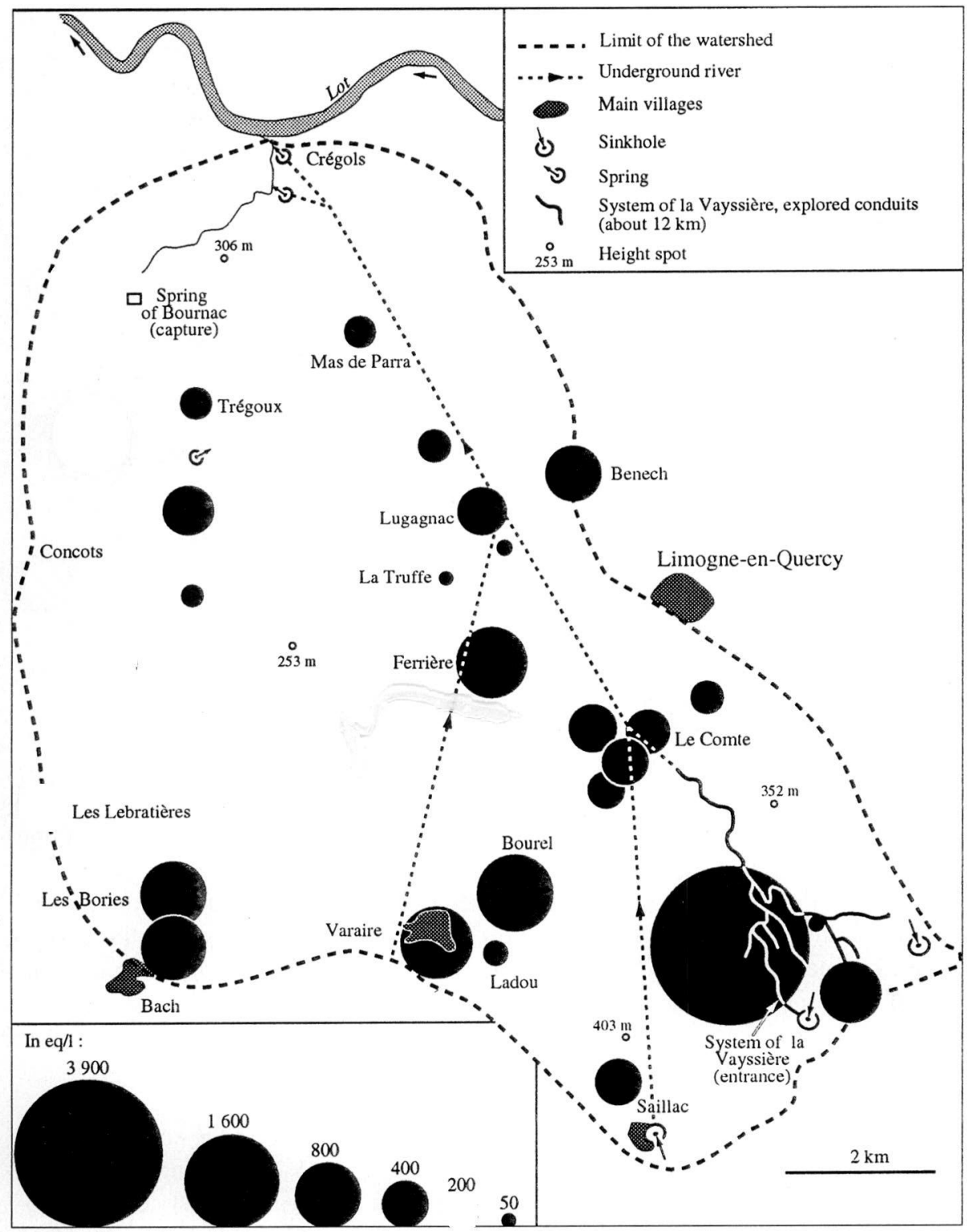

Fig. 3. Potential pollution of the Causse of Cregols. 
the Lot, the Causses and Quercy Blanc show that there has been a considerable increase: some peaks exceeded $100 \mathrm{mg} / \mathrm{l}$ (up to $160 \mathrm{mg} / \mathrm{l}$ at Lacave-Rocamadou), when C.E.E. limits should not exceed $25 \mathrm{mg} / \mathrm{l}$.

In many karst regions, pollution has reached levels that pose a threat to public health, to babies and consumers in general. Some water supply catchments have already been abandoned. For a long time diffuse and slight agricultural pollution has been neglected, in spite of the low capacity of karst areas for self-cleansing. it was then denied by agricultural lobby, or sidelined by water supply authorities, who always advocate the treatment option in preference to prevention. But today pollution has reached a level that can no longer be tolerated, and its origins have been clearly identified. The authorities have the duty to act for the protection of karst and consumers.

\section{Protection measures}

The best protection would obviously be to have no activity on the karst, but this is clearly unacceptable, as it threatens the farmers existence. Solutions that are acceptable to everyone must be found.

\subsection{The need for purification of water upstream of karst underground systems}

A first set of measures would consist of separating rainwater from waste water. For that it would be necessary to ensure an impermeable layer in cattle sheds and stables in order to collect liquid manure and leaching from silage, and to treat water from washing down by collecting it in impermeable troughs. The aim is to reduce pollution before it penetrate the karst.

Then, in the absence of any effective natural filter, which karst soils do not provide, it would be necessary to create dispersion sites, with multiple levels of thick filtering beds. Karst protection requires a preliminary treatment of effluent and agricultural wastes, instead of the simple, traditional method of dispersion. Finally, the promotion of composting and drying of liquid manure are methods which deserve consideration. To reduce turbidity, it would be sensible to manage wastes: installing filters, stone-works, channels, etc.

This development will not be easy to achieve, as the techniques recommended here mean an extra production cost, but in many cases this is less than the cost of water treatment at springs. A comprehensive programme of information and publicity of the issues to the farming community must be instigated as soon as possible, to ensure the acceptance of these measures.

\subsection{Defining water protection areas}

The need to protect the catchment of karst springs dates from the end of the 19th Century when Paris, which had obtained its water from Vanne spring in the Othe forest via a long aqueduct since 1862, had to extend the area of forest cover to protect the springs. From early this century, the role of E. A. Martel in Public Health is well known. But the extent and complexity of the catchment of karst springs creates 
a difficult problem in defining areas of protection and causes conflict between the rural environment and the urban consumers. Thus, the idea of legally well defined protection zone can, when implemented, clash with local economic constraints and with the lack of knowledge about karst and its hydrology. A few examples illustrate this problem.

\section{1 - Delimitation of the protection zone of Arcier spring (Doubs)}

This powerful spring, which was used in Roman times, has been used for Besançon's water supply since 1854 . After a series of typhoid epidemics, a treatment plant was built to suppress bacterial pollution. But the recent growth in nitrates and nitrites necessitated a precise definition of the catchment area by extensive water tracing (Mettetal, 1985). This has revealed that it consists mainly of the polje of the Marais de Saône, which receives the leaching from agricultural land and effluents from small treatment plants in neighbouring villages, discharged through the Creux de la Roche stream-sink.

\section{2 - Protection zone of the Lez spring (Herault)}

The spring has supplied Montpellier by aqueduct since 1976. An increase in withdrawals, firstly by abstraction in the spring basin, then by pumping (1982) from the drowned conduit of the vauclusian spring, has changed the hydrological circulation in the karst system and made it necessary to define extensive protection zones. Multiple research (Avias, 1994) has enabled us to define:

- a protection zone including all the neighbouring limestone plateaus $\left(150 \mathrm{~km}^{2}\right)$, all the Causse of Viols le Fort, which make up the spring's main catchment area;

- an extended area, where there are probable connections between aquifers (positive water tracings), but where protection is limited to sensitive areas (near water courses experiencing water loss).

The protection zone which was suggested in 1979 was refused by the rural communes involved. Long negotiations were necessary ${ }^{4}$, requiring financial compensation and water supply from a new catchment for the protesting communes. The example of the recent contamination by effluent from the treatment plant at St. Martin de Triviers shows that monitoring (requiring the intervention of biologists specialising in underground fauna) remains necessary (Malard et al., 1997).

\section{3 - Inclusion of karst areas in protected natural parks}

There are currently a number of karst plateaus and massifs included in the boundaries of regional parks: Upper Jura, Bauges, Chartreuse, Vercors, Luberon, Grands Causses, Quercy and Verdon. However, since the limits of these parks are determined by the wishes of the communes involved, they do not necessary coincide with the extent of natural karst areas or the protection zones of the spring. Thus the Luberon regional park only covers a small part of the Vaucluse plateaus, as is the case

${ }^{4}$ A decree of 1981 reduced the boundary to enclosed $1 \mathrm{~km}^{2}$ ! 
of the Grands Causses park compared to the extent of the Causses. It is true that the eastern part of the Grands Causses is included in the Cevennes National Park.

Having said this the statute for regional park, an important aspect of its action is devoted to the protection of water resources, especially the Larzac aquifers. This protection, which is assured by the communes involved, but with financial and technical aid from the park authorities, includes the delimitation of hydrological basins, the monitoring of water sites, the protection of caves and underground fauna. There is an attempt to improve the treatment of waste water, in particular pilot systems to treat waste water have been installed in isolated farms. The park is a party to the protection of springs and rivers.

The restoration of the classic landscape (Grands Causses, Quercy) is under discussion with local farmers: clearing the undergrowth, re-establishing grass pasture for sheep and rabbit breeding. Specific heritage actions include the restoration of farms in picturesque hamlets with their dry-stone walls (Roques Altes, on the Causse Noir), ponds and public wash-houses.. Explanatory signs (Planagreze) and marked paths attempt to make summer tourists aware of the landscape and heritage of the Causses (Renard, 1998). They try to capitalise on the attractions of the large show caves (Padirac, Dargilan, Aven Armand), caves with cave paintings (Pech Merle, Quercy), and water recreation in the beautiful river gorges.

The impact of modern agriculture on karst areas and the protective measures, whether undertaken or planned, cannot escape the two classic environmental dilemmas:

- between economically profitable agriculture and ecological protection;

- between a general laissez-faire policy and local protection (parks currently represent about $10 \%$ of the area of France).

\section{Conclusion}

The protection of karstic agricultural environments is made difficult by their diversity and the complexity of actions and interactions, but we must remember that the need to protect spring water that was recognised thanks to the impartial actions of speleologists (Renault, 1990). Multidisciplinary research in progress involving hydrogeologists, geomorphologists, hydrobiologists, agronomists, etc. reveals the diverse aspects of how karst functions, and suggest solutions to the problems identified. There is everything to be gained by adopting solutions that avoid pollution: treating the effects of pollution, particularly for drinking water, will become economically more and more expensive compared to prevention of pollution; both ecologically and aesthetically, upstream prevention of pollution is much more satisfactory solution.

\section{ACKNOWLEDGEMENTS}

We would like to express our gratitude to all our colleagues, who have provided us with information and comment: Ambert P. (CNRS-Montpellier), Astruc J.G. (BRGMToulouse), Audra Ph. (Nice), Bruxelles L. (Montpellier), Denneville (PNR Millau), Gaiffe M. 
(Besançon), Guendon J.L. (Aix), Puig J.M. (Avignon) Tarrisse A. (Cahors), Vaudour J. (Aix) et Williams G. \& P. (Auckland).

\section{REFERENCES}

AMBERT P., MARTIN Ph., GUENDON J. L., 1992 - Le Karst de la Source del'Espérelle (Larzac NE). Etude hydrogéomorphologique, Rapport, 42 p.

AUDRA Ph., 1998 - Erosion des sols et pollution des eaux dans une région de viticulture intensive: exemple du karst de l'Entre-deux- Mers. I.A.H.

AVIAS J., 1994 - A methodical approach of karstic aquifers. "Vulnerability mapping" in Karstic areas from the experience of "Source du Lez karstic basin vulnerability map". COST 65 Action, pp. 129-135.

BAKALOWICZ M., RICARD J., 1994 - Karst aquifers of the Grands Causses (F) water reserves that must be protected. COST 65 Action, pp. 137-148.

BLAVOUX B., MUDRY J., PUIG J.M., 1991/1992 - Bilan, fonctionnement et protection du système karstique de la Fontaine de Vaucluse. Géodinamica Acta, 5 (3): 154-172.

BRUXELLES L., 1995 - Etude des formations superficielles et endokarstiques du causse de l'Hospitalet (Larzac). Mém. DEA Aix-en-Provence, 62 p. 5 cartes.

CABROL P., 1989 - Causes de dégradation du milieu souterrain. Spelunca $n^{\circ} 35: 12-18$.

CASANOVA J., 1986 - Perte de pouvoir des Cyanophycées constructives de travertins lié à la pollution, l'exemple de l'Huveaune (Var). Méditerranée, 1 (2): 179.

CONRAD G. et al., 1988 - Karst et Quaternaire de la Basse-Seine. Colloque Actes Muséum de Rouen.

COHEN M., 1995 - Usages pastoraux et dynamique des parcours caussenards. L'Espace géographique $\mathrm{n}^{\circ} 1$ : $60-75$.

COUSTOU J.C., 1979 - Pollution du système karstique de l'Ouysse, Causse de Gramat (Lot). Spelunca $\mathrm{n}^{\circ} 1: 23-26$.

C.R.E.P.S.C., 1981 - Pollution des eaux souterraines des karsts et ses conséquences en Franche-Comté. Actes IV Colloque Nat."Protection des eaux souterraines", Besancon, pp. 1352.

CREUZÉ des CHATELIERS M., TURQUIN M.J. and GIBERT J., 1991 - Les aquifères des systèmes biologiques. BRGM, Hydrologie $n^{\circ} 3:$ 163-185.

DODGE D., 1982 - Mise en évidence par tracage d'une éventuelle pollution des eaux souterraines du Causse Comtal. 3ème Coll. Hydrogéol. en Pays Calcaire, Ann. Scient. Besançon, pp. 89-96.

DOUAT M. et SALOMON J-N., 1994 - Nouveaux tracages dans le massif de la Pierre-StMartin. Karstologia ${ }^{\circ}$ 23: 9-18.

DUBREUCQ F., CHAUVE P., MANIA J., BRUCKERT S. et al., 1988 - Rôle de l'interface sol-roche sur l'acquisition du chimisme des eaux. Ann. Scient. Besançon, Mém. 6 (II): 347364.

FABRE G. and MAURIN Y., 1985 - Environnement et hydro-pollution du site du Bramabiau dans les Grands Causses. Ann. Soc. Géol. Belgique, 108: 49 - 53. Fédér ation Française de Spéléologie - 1993 - Menaces sur le milieu souterrain. Les Cahiers du C.D.S., $n^{\circ} 4$.

GAIFFE M. and BRUCKERT S., 1985 - Analyse des transports de matière et processus pédogénétiques impliqués dans la chaine de sols des karsts juras siens. Soils and Geomorphology, Catena Suppl. 6: 154-174.

GAMEZ P., 1995 - Hydrologie et karstologie du bassin du Loison (Woëvre septentrionale, Lorraine). Mosella, Metz. 
GAMS I., NICOD J., JULIAN M., ANTHONY E. and SAURO U., 1993 - Environmental Change and Human Impacts on the Mediterranean Karsts of France, Italy and the Dinaric Region. Catena Suppl. 25: 59-98.

GAUCHON Ch., 1997 - Des cavernes et des hommes, Géographie souterraine des montagnes francaises. Karstologia Mémoires ${ }^{\circ} 7$.

GUILLEMIN C. and ROUX J. C., 1992 - Pollution des eaux souterraines en France. Manuels et Méthodes, B.R.G.M. ${ }^{\circ} 23$.

HOBLEA F., 1990 - Problèmes d'aménagement sur karsts d'altitude voués au tourisme. Bull. Labo. Rhodanien de Géomorphologie (Lyon) n 25/26: 67-82.

MAIRE R., 1979 - Comportement du karst vis à vis des substances polluantes. Ann. Soc. Géol. Belgique, 102: 101-108.

MAIRE R., 1990 - La Haute Montagne calcaire. Thèse Etat. Univ. Nice, Karstologia Mém. $\mathrm{n}^{\circ} 3$.

MALARD F., GIBERT J. and LAURENT R., 1997 - L'aquifère de la source du Lez: un réservoir d'eau et de bio-diversité. Karstologia n 30: 49-54.

MANGIN A. and ANDRIEUX M., 1987 - Infiltration et environnement souterrain. Actes Journ. F. Trombe.

MANGIN A. and BAKALOWICZ M., 1989 - Orientation de la recherche scientifique sur le milieu karstique influences et aspects perceptibles en matière de protection. Spelunca $\mathrm{n}^{\circ} 35$ : 71-79.

MARRES P., 1935 - Les Grands Causses - t. II. Le Labeur Humain, Arrault,Tours.

MARTIN Ph., 1991 - Hydromorphologie des géosystèmes karstiques des versants nord et ouest de la Sainte-Baume; étude hydrologique, hydrochimique et de vulnérabilité à la pollution. Thèse Univ. Aix-Marseille II.

METTETAL J. P., 1985 - Etude préalable à la définition des périmètres de protection en milieu karstique: ex. de la Source d'Arcier. Hydrogéologie, B.R.G.M. n ${ }^{\circ}$ : 235-242.

MOREAU R., 1982 - La pollution des eaux karstiques: hygiène et épidémiologie. In La protection des eaux karstiques, SNDE Bruxelles, pp. 4-32.

MOURET C., 1984 - Les effondrements en milieu karstique: un risque important pour l'aménagement du territoire. In Mouvements de terrains, Colloque de Caen, Doc. B.R.G.M. $n^{\circ} 83$.

NICOD J., 1984 - Instabilité de dépressions karstiques. In Mouvements de terrains, Colloque de Caen, Doc. B.R.G.M. n' 83 : 274-278.

NICOD J., 1990 - Quelques problèmes d'aménagement de dépressions karstiques. Actes 115ème Congrès Soc. Savantes, Avignon, CTHS, pp. 19-37.

NICOD J., 1991a - Impacts des déboisements et défrichements récents. Actes 116ème Congrès Soc. Savantes, Chambery, CTHS, pp. 53-66.

NICOD J., $1991 b$ - Les problèmes du lac de Besse (Var). Karstologia n 17: 54-55.

NICOD J., 1995 - Carte géomorphologique des karsts de France. Karstologia n 25: 21-34.

P.N.R., 1996 - Compte-rendu d'activité du Parc Naturel Régional des Grands Causses. Millau.

POREL C., RAZACK M. et al., 1994 - The karst environment of the urban district of Poitiers, its features and water ressources management and protection. COST 65 Action, pp.11-123.

RENARD A., 1998 - Le patrimoine touristique naturel et architectural des Causses de Cahors. Mem. Inst. Géogr. Univ. Bordeaux-3.

RENAULT Ph., 1990 - Agression sur le karst, synthèse et développement. Spelunca n³9: 25-34. 
RODET J., 1982 - Karst et environnement en zone urbanisée. Spelunca ${ }^{\circ}$ 35: 66-70.

RODET J., 1992 - Les Karsts de la Craie. Thèse Univ. Paris IV; Centre Normand d'études du karst.

ROVERA G., 1990 - Géomorphologie et aménagement des versants moyenne Tarentaise. Thèse Univ. Grenoble.

RICARD J. and BAKALOWICZ M., 1996 - Connaissance, aménagement et protection des ressources en eau du Larzac. Doc. B.R.G.M.

SALOMON J-N., 1997 - L'Homme face aux crues et aux inondations. Collection "Scieteren", Presses Universitaires de Bordeaux.

SALOMON J-N. and TARISSE A., 1998 - Le karst face à l'agriculture productiviste, l'exemple du Quercy. Rev. Sud-Ouest Européen n ${ }^{\circ}$ 3, Toulouse, (sous presse).

SALOMON J-N., 1999 - Hydro-karsto-spéléologie des Causses de Cahors. Carte en couleur et notice, Karstologia (sous-presse).

TRABAUD L., 1980 - Impact biologique et écologique des feux sur l'organisation de la structure et l'évolution de la végétation des zones de garrigues du Bas-Languedoc. Thèse USTL Montpellier.

TREFFOT G., 1992 - Karst, aménagement et environnement dans le Bassin Parisien. Karstologia $n^{\circ}$ 19: 51-58.

VANARA N., 1998 - Le karst du Massif des Arbailles (Pyrénées occidentales); controle climatique hydrogéologique et anthropique. Thèse Univ. Bordeaux 3.

VAUDOUR J., 1986 - Travertins holocènes et pression anthropique. Méditerranée, t. 57 (1-2). 